\title{
Cartographic Reconstruction of Historical Environmental Change
}

\author{
Martin C. Lukas \\ Sustainability Research Center (artec), Bremen University \\ martin.lukas@uni-bremen.de
}

\begin{abstract}
Historical maps provide large potential for research into historical environmental change. However, the limited availability and accuracy of early cartographic material restricts the analytical time scale of inquiry and poses methodological challenges. An important consideration in this context is the question: at minimum, how accurate must historical maps be in order to be used for which kind of analysis. This question is addressed here, based on the example of a combined analysis of historical maps and satellite images that aimed at reconstructing shoreline aggradation in the Segara Anakan lagoon on the south coast of Java. I present a practical methodological approach to analyzing historical spatial information which has varying degrees of accuracy. In the example presented, this approach links an accuracy assessment of selected historical maps of the region with a lagoon shoreline change analysis. As indicators for the maps' analytical suitability and the reliability of results, I propose ratios between environmental change rates and quantitative map accuracy measures, as well as combined uncertainty measures. The empirical example demonstrates that in case of large magnitudes of environmental change an analysis of even fairly inaccurate historical maps can provide results with surprisingly low levels of uncertainty. However, large magnitudes of environmental change can also constrain the analysis of historical maps. Quantitative analyses of the accuracy and the contents of historical maps should be accompanied by a qualitative appraisal taking into account carto-bibliographic information and the various dimensions of map accuracy. The maps of change presented in this paper may support further inquiry into the dynamics and drivers of environmental change in the Segara Anakan lagoon region.
\end{abstract}

KEYWORDS: historical maps; historical cartography; map reliability; map accuracy; planimetric accuracy; historical environmental change; shoreline reconstruction; coastal sedimentation; Segara Anakan lagoon; Java; Indonesia

\section{INTRODUCTION}

HistoricAl MAPS ARE OFTEN the only source of historical spatial information. The digitization and reproduction of archival material has tremendously enhanced the accessibility of historical maps, while GIS has made accuracy assessment, correction, and analysis possible and efficient. This in turn facilitates the linking of historical maps with recent spatial information, providing larger potential than ever for research into environmental histories. Historical maps, often embedded in GIS, have proven valuable for the analysis of land use / cover changes (Haase et al. 2007), coastal features (Crowell, Leatherman, and Buckley 1991; Jabaloy-Sanchez et al. 2010; Levin 2006; Monmonier 2008), settlement processes (Levin, Kark, and Galilee 2010), agricultural histories (Pearson and Collier 1998), soil degradation (Brookfield 1999), salt marsh losses (Bromberg and Bertness 2005), and river meanders (Słowik 2013). Historical maps can help to verify, concretize, or dismantle narratives about past environmental changes and political events (e.g., Brookfield 1999; Pearson 2005).

Knowledge about past environmental changes is crucial for a realistic understanding of contemporary environmental issues, because current conditions and processes are partly an outcome of long-term developments, and the nature and pace of current dynamics can only be realistically evaluated against the backdrop of past developments. In this context, our choice of analytical time scales is an important consideration, since it may influence our results and conclusions (Batterbury and Bebbington 1999; 


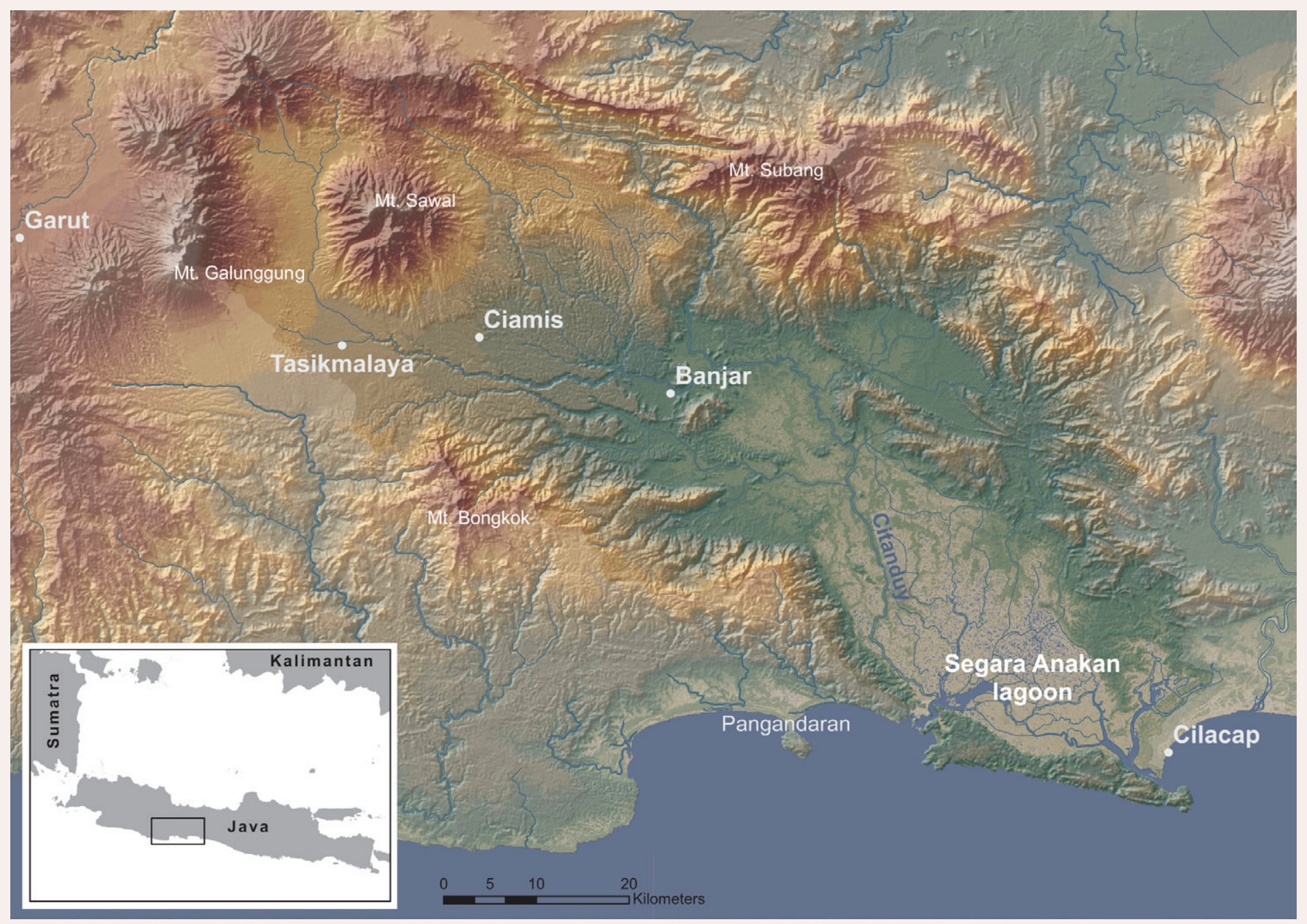

Figure 1. Location of the Segara Anakan lagoon and its catchment area on the south coast of Java.

Chapman and Driver 1996). For a realistic understanding of anthropogenic drivers, it is particularly interesting and meaningful to incorporate times of transition from mainly nature-dominated to human-dominated landscapes (Batterbury and Bebbington 1999; Messerli et al. 2000).

However, the further we expand our analytical time scale into the past, the more our inquiry is constrained by the limited availability and accuracy of historical cartographic material. While contemporary remotely sensed material provides very precise and accurate images of almost the entire world at resolutions of a few meters or less, historical topographic maps from the nineteenth or early twentieth century may be marked by inaccuracies of tens or hundreds of meters, and earlier charts may only depict a small range of selected topographic features and include completely uncharted territories. In this context, careful evaluation of the cartographic material's reliability is crucial. This should include a thorough exploration of the history of mapping of the target region, the gathering of knowledge about mapmakers and mapmaking processes, and a careful examination of the maps' accuracy (Levin 2006; Jenny 2006). One important question at this juncture is: how accurate does the cartographic material need to be, at minimum, in order to be used for which kind of analysis?

I address this question here, based on the example of a combined analysis of historical maps and satellite images which aimed at reconstructing shoreline aggradation in the Segara Anakan lagoon on the south coast of Java. I present some of the valuable but largely underutilized historical cartographic material of the region and an assessment of its accuracy. Linking map accuracy with the results of the shoreline change analysis, I propose ratios between environmental change rates and quantitative map accuracy measures, as well as combined uncertainty measures as indicators for the maps' analytical suitability and the reliability of results. 


\section{RATIONALE AND CONTEXT: THE SHRINKING SEGARA ANAKAN LAGOON}

THE RESEARCH PRESENTED HERE aimed at contributing to an improved understanding of environmental changes in the Segara Anakan lagoon. This shallow coastal lagoon on Java's south coast (Figure 1) has been heavily impacted by riverine sediments. Rapid aggradation is said to have contributed to a vicious cycle of diminishing marine resources, environmental degradation and poverty (Bird, Soegiarto, and Soegiarto 1980; Dudley 2000; Olive 1997; White, Martosubroto, and Sadorra 1989; Yuwono et al. 2007; Purba 1991).

Despite a long record of research and political interventions in the area, knowledge of the historical dynamics and drivers of sedimentation remains limited, and related discussions have been dominated by political discourses (Lukas 2013; 2014). While these discourses have focused on upland agriculture, other drivers of sedimentation have been neglected (ibid.). Knowledge of the temporal dynamics of lagoon sedimentation may contribute to exploring its various drivers. In this context, the research presented here aimed at reconstructing lagoon shoreline aggradation, with an analytical time scale expanding as far back as the availability and accuracy of historical cartographic material allowed. The results-a delineation of historical shorelines-illustrate the rapid pace of transformation and provide a rough, albeit only two-dimensional, picture of the temporal dynamics of lagoon sedimentation. The maps of change presented below may support further research into the environmental history of this area.

Historical shoreline reconstructions of the Segara Anakan lagoon already exist (Schaafsma 1926; Hadisumarno 1964; Hadisumarno 1979; ASEAN/US CRMP 1992; PRCECI 1987; Soewondho 1984; ECI 1994; Tejakusuma 2006). However, these analyses only cover the twentieth century and lack adequate documentation of data sources, methods, and map accuracy. In addition, their results are partly erroneous. For example, Hadisumarno (1964; 1979) did not pay attention to the time gap between the dates of surveys and map publication. The dramatic increase in his annual aggradation rates for the lagoon's eastern shoreline from $5 \mathrm{~m}$ for the period $1900-1940$ to $54 \mathrm{~m}$ for the period 1940-1946, which he interpreted as a result of "deforestation within the river catchment area of Citandui during the Japanese occupation," (49) in fact largely resulted from his neglecting the fact that the maps from the 1940s were based on surveys already carried out in the 1920s. The same error appears in the shoreline change maps subsequently included in various project documents (ASEAN/ US CRMP 1992; PRC-ECI 1987; Soewondho 1984; ECI 1994). A well-documented shoreline change analysis is contained in the findings of a land use change analysis by Ardli and Wolff $(2008$; 2009), but it only covers the period from the 1970s onwards.

\section{ACCURACY OF THE HISTORICAL MAPS OF JAVA'S SOUTH COAST}

THE ERRORS IN PREVIOUS shoreline change analyses underline the importance of obtaining background information about mapmakers and mapmaking processes before using the content of the cartographic material for analysis. Systematically gathering as complete an account of historical maps of an area as possible, ordering them in a temporal sequence, connecting them with information on the processes of their making, and analyzing their accuracy supports the selection of the most suitable material, with as small a temporal resolution and as large a temporal scale as possible, and helps to realistically assess the varying reliability of the material.

\section{OVERVIEW OF THE MATERIAL}

As a basis of the research presented here, more than 50 different historical maps and map series produced between the sixteenth and twentieth century were gathered from various libraries and archives worldwide. An overview of this material along with information about mapmakers and mapmaking processes is provided in Lukas (forthcoming). Accordingly, the earliest known maps of the Segara Anakan lagoon or parts thereof go back to cartographic expeditions undertaken on behalf of the United (Dutch) East India Company in 1698, 1711, and 1739 (Schilder 1981; Schilder 1978; Knaap et al. 2007). The manuscript sea charts drawn during these voyages remained the only original cartographic documentation of the lagoon until the early nineteenth century. One of them is depicted in Figure 2. The first fairly detailed maps of the entire lagoon were produced in 1809 by Jan Theunis Busscher (Figure 3) and in 1813-15 as part of the first systematic topographic large-scale mapping of Java (Figure 4). Additional increasingly detailed maps were produced 


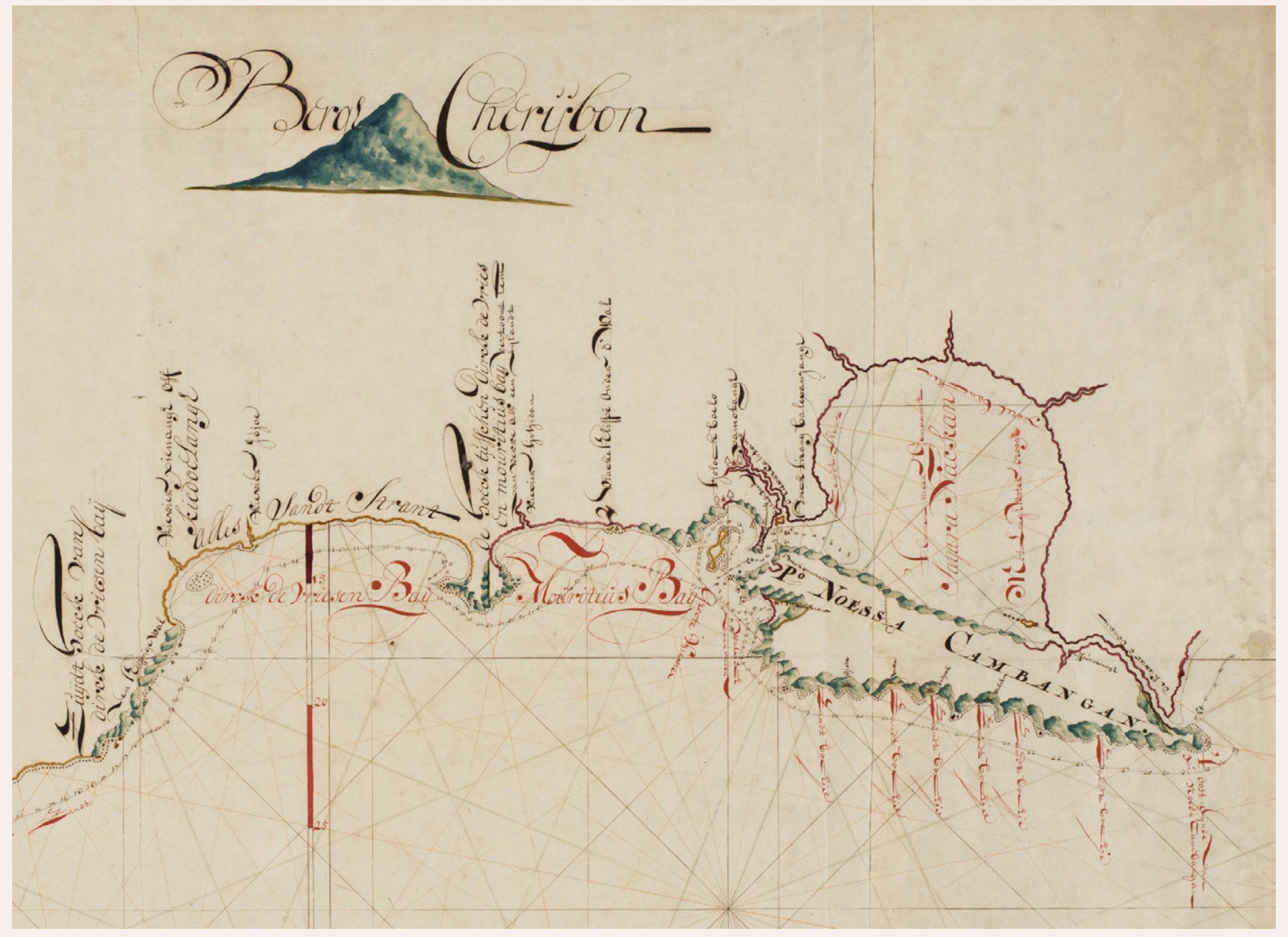

Figure 2. This section of the manuscript sea chart drawn by Cornelius Coops in 1698 is the earliest known map of the Segara Anakan lagoon. Original scale: approx. 1:140,000. Retrieved from the Netherlands National Archives in The Hague.

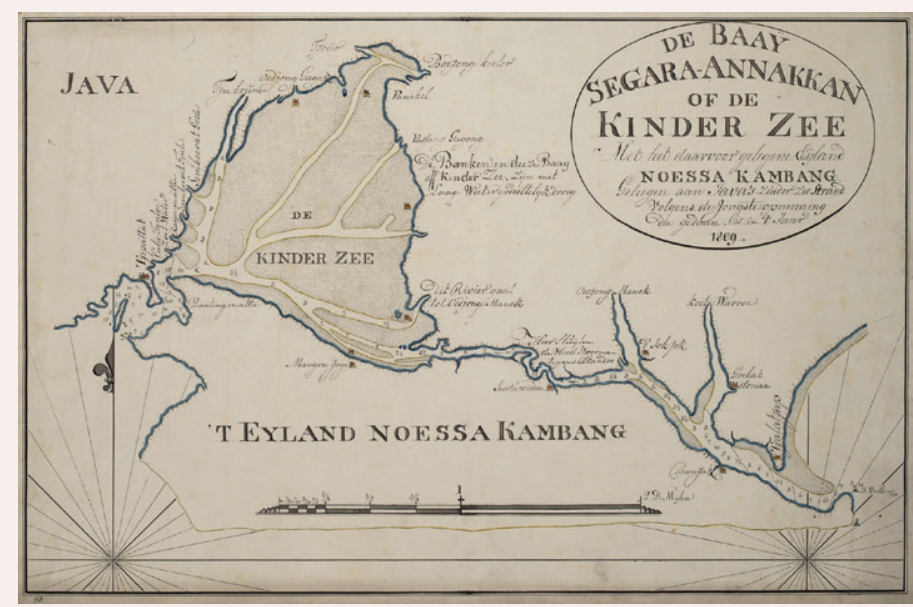

Figure 3. Map of the Segara Anakan lagoon, drawn by Jan Theunis Busscher in 1809. Original scale: 1:76,000. Retrieved from the Netherlands National Archives in The Hague.

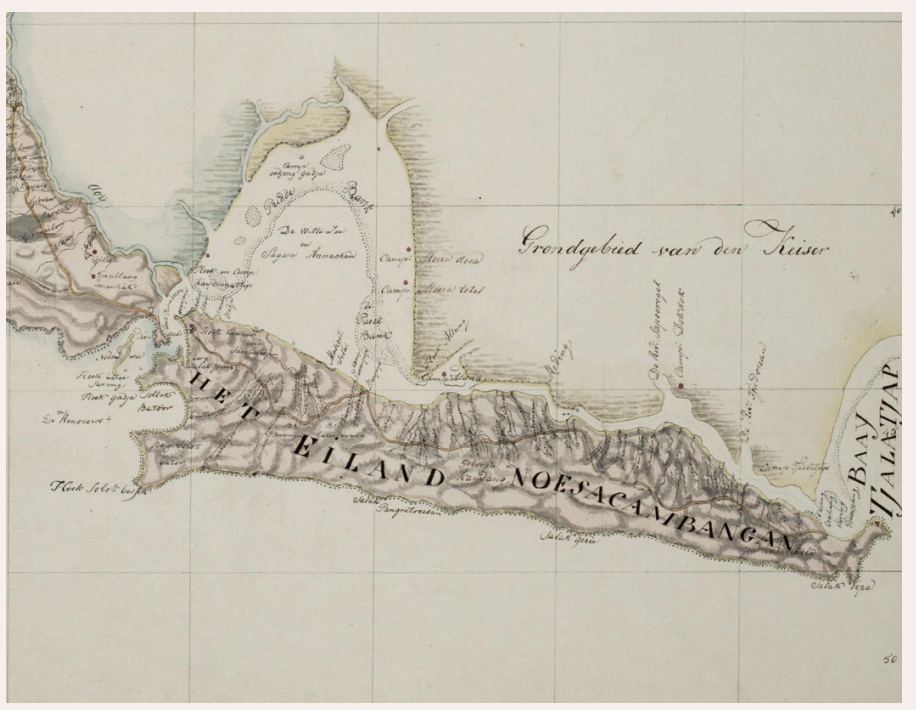

Figure 4. Section of Sheet 20 of the Kaart der Preanger Regentschappen en Crawang, based on surveys carried out between 1813 and 1815. Original scale: 1:114,000. Retrieved from the Netherlands National Archives in The Hague. 


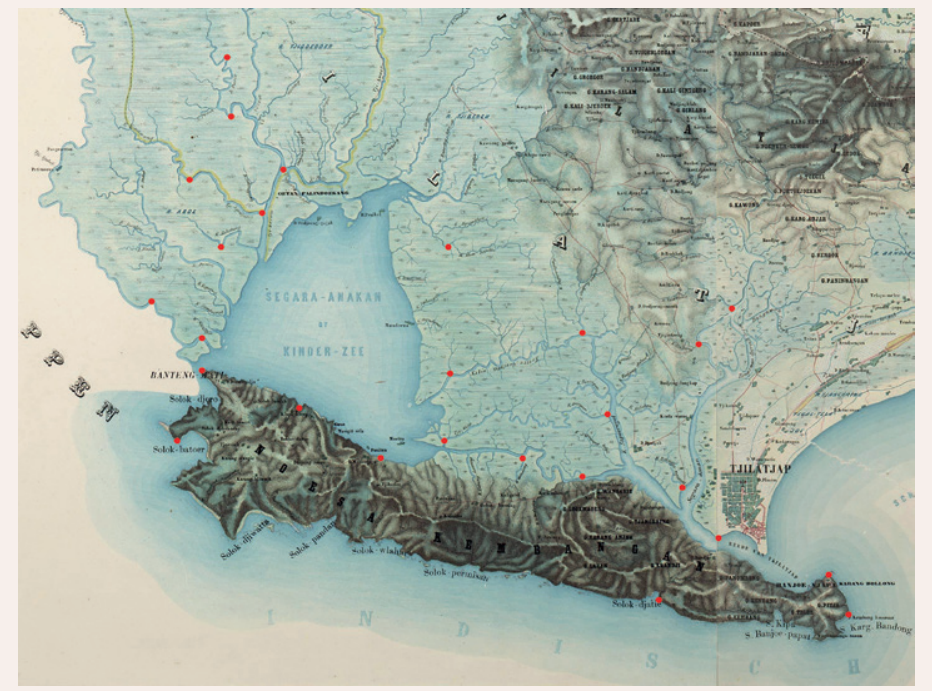

Figure 5. Section of the Topographische Kaart van de Residentie Banjoemaas, based on surveys carried out between 1857 and 1860. Original scale: 1:100,000. Retrieved from the Netherlands Royal Tropical Institute (KIT). The red points represent the ground control points used for georectification.

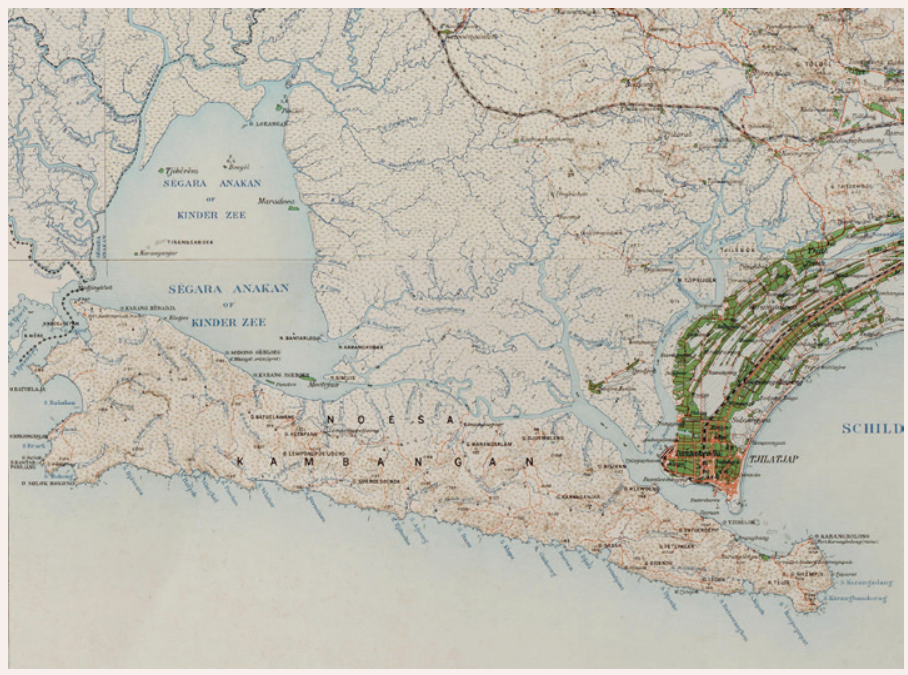

Figure 6. Topographic map of Java, Residency Banjoemas, produced by the Topographical Service in the Netherlands East Indies (TDNI), based on surveys carried out between 1897 and 1901. Compilation of sections of map sheets III, IV, VII, and VIII. Original scale: 1:100,000. Retrieved from KIT.

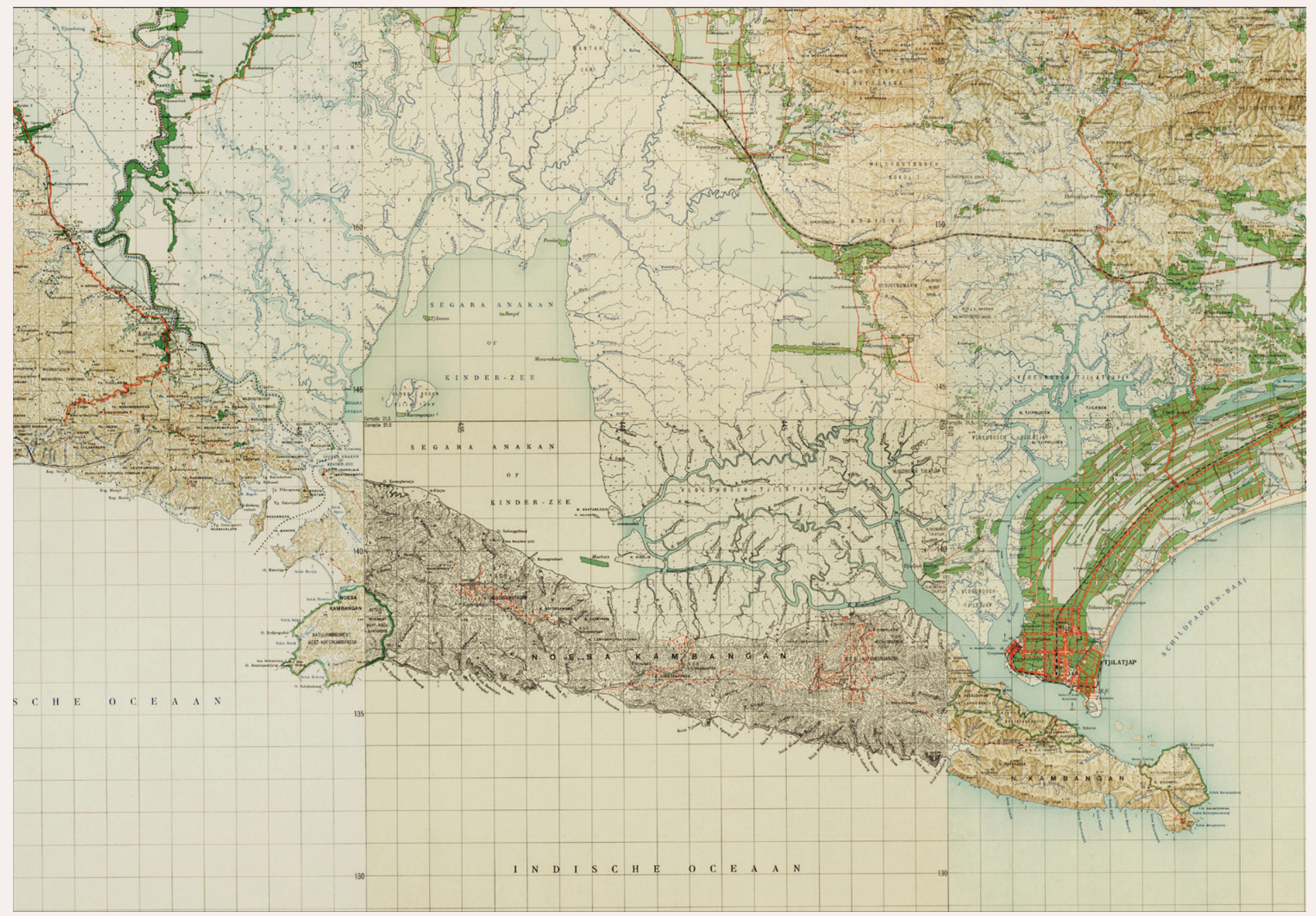

Figure 7. Topographic map of Java, Middle and West Java, produced by TDNI, mainly based on surveys carried out between 1924 and 1926. Compilation of sections of map sheets 42/XLI D, 43/XLI C, 43/XLI D, 42/XLII B, 43/XLII A, 43/XLI D. Original scale: 1:50,000. Retrieved from KIT. 


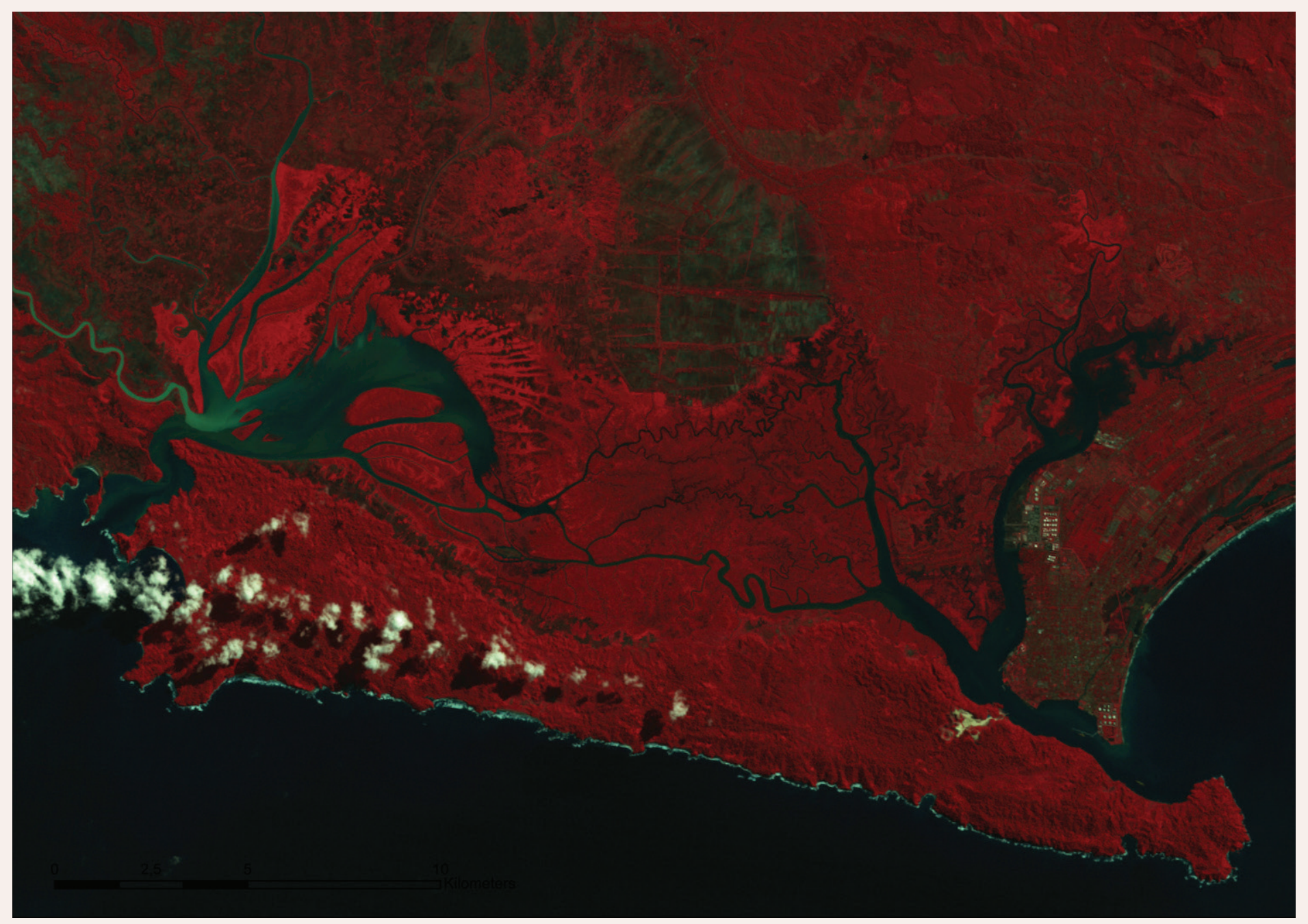

Figure 8. Section of a Landsat image depicting the Segara Anakan lagoon in 1993. Landsat TM, resolution: 30m, date of acquisition: 23.05.1993. Retrieved from BTIC Dataport, Indonesia.

as part of subsequent topographic surveys in 1857-60, 1901-04 and 1924-26 (Figures 5-7). A map series produced by the US Army between 1939 and 1944 did not provide new topographic information, but was based on the previous topographic maps. Following several decades without any update of the cartographic knowledge of this area, a Corona satellite image from 1962 is the next temporal layer of lagoon shoreline information that could be found (available from the US Geological Survey). From the 1970s, Landsat images provide an easily accessible basis for analyzing environmental changes in most parts of the world, including the Segara Anakan lagoon (also available from the USGS). And since the 1980-90s, remotely sensed data from various satellite missions offer analytical possibilities that, with regard to temporal and spatial resolution and accuracy, completely outshine those provided by early topographic maps from the nineteenth century, not to mention the early manuscript sea charts from the seventeenth and eighteenth century.

A brief glance at the historical cartographic material outlined above unsurprisingly indicates that the reliability of the material continuously declines the further we go back in time. Yet if the temporal scale of our analysis is to cover more than only the past few decades-and to truly understand today's environmental dynamics often requires looking further back-we need to combine the analysis of satellite images with the analysis of clearly less accurate early topographic maps. An important consideration in this context is the question where the extent of map inaccuracy delimits the temporal scale of a historical cartographic analysis. The next two sections outline the dimensions of map accuracy and present an accuracy analysis of selected historical maps of the Segara Anakan lagoon region. 


\section{DIMENSIONS OF MAP ACCURACY}

The accuracy of historical maps is affected by factors like topographic knowledge, the methods of surveying, map drawing, and reproduction as well as paper deformation processes, such as shrinking or stretching (Jenny and Hurni 2011). The contribution of each of these factors can often not be determined (Jenny 2006). Following Laxton (1976), Blakemore and Harley (1980), Levin et al. (2006; 2010), and Jenny and Hurni (2011), accuracy assessment can comprise four dimensions: (1) topographic accuracy, referring to the quantity and quality of information about landscape features; (2) chronometric accuracy, referring to the dating of the map and the information therein; (3) geodetic accuracy (or coordinate grid accuracy), referring to the positioning of the map in the coordinate system; and (4) planimetric accuracy (or feature or geometric accuracy), referring to the positions, distances, areas, and angles of features on the map as compared to those in reality.

1. The topographic accuracy of the maps of Java's south coast continuously increased over time, with the early manuscript sea charts of the seventeenth and eighteenth century only depicting a few major bays and capes and at best showing a rough outline of (parts of) the Segara Anakan lagoon (see Figure 2), and the topographic maps from 1860, 1901-1904 and 1924-26 depicting shorelines and various other topographic features with increasing completeness (see Figures 5-7).

2. The errors in earlier historical cartographic analyses of the Segara Anakan lagoon caused by ignoring the time gaps between survey dates and the maps' publication dates demonstrate the importance of assessing the chronometric accuracy of the material. Dating the information contained in historical maps may require knowledge of mapmakers and mapmaking processes. Access to this information has greatly improved with the digitization and reproduction of archival material in recent years. The surveying and publication dates of the maps depicted in Figures 2-7 are provided in Table 1. Based on this, the shoreline data that were extracted from the maps and that are presented below are consequently dated in line with the year of topographic data collection rather than the year of map publication.
3. Assessing the geodetic accuracy of the maps presented is rather problematic, since in most cases no coordinates and gridlines are depicted, and map projections are unknown. This is often the case with historical maps (Jenny and Hurni 2011). Many of the earlier maps of Java from the seventeenth and eighteenth century were not yet based on conformal projections, even though the conformal Mercator projection had been introduced as early as around 1570 (Schilder et al. 2006, 22). Geodetic inaccuracy can lead to errors in the positioning of features. However, such errors are often of minor importance in relation to planimetric inaccuracies (Jenny and Hurni 2011; Locke and Wyckoff 1993). This can be assumed to be particularly true in case of the research presented here, given the small size of the study area, the comparably large scale of the maps and the location close to the equator. The non-existence of any systematic single-directed deviation in the maps presented, as indicated by the displacement vectors, which visualize positional errors after georectification, confirms that potential geodetic inaccuracy is of minor importance.

4. The planimetric accuracy can be quantified by comparing the locations of features on historical maps with their "true" locations on more accurate, recent topographic maps, on remotely sensed images, or as measured in the field using GPS (Levin, Kark, and Galilee 2010). By comparing the positions of at least four such locations with the help of tools included in programs such as ArcGIS or MapAnalyst, the Root Mean Square Error (RMSE) can, in the case of negligibly small geodetic inaccuracies, be determined as the median planimetric location error. It can be given in millimeters at map scale or in meters at real world scale. With MapAnalyst, the extent and spatial variation of this error can be visualized in the form of distortion grids or displacement vectors (Jenny 2006; Jenny and Hurni 2011). The planimetric accuracy of historical maps differs greatly depending on the period and the region, but also on the scale of the maps. An example of very early maps with exceptionally high levels of planimetric accuracy are those drawn of the region around Dresden, Germany by M. Öder in the late sixteenth century. With mean planimetric errors of only about $100 \mathrm{~m}$ at real world scale, they are perhaps the most 
accurate maps of their time worldwide (Bönisch 1967). Levin, Kark, and Galilee (2010), to mention one more example out of a larger number of similar studies, determined mean errors between $71 \mathrm{~m}$ and $780 \mathrm{~m}$ at real world scale for historical maps of Palestine produced between 1880 and 1946 at scales between 1:20,000 and 1:250,000, and errors at a magnitude of several kilometers for maps produced earlier.

\section{QUANTITATIVE PLANIMETRIC ACCURACY ASSESSMENT}

For the maps depicted in Figures 2-7 and the Corona image, median planimetric errors were determined by comparing point locations identified on the historical material against those on recent topographic maps, applying the following steps:

The maps were scanned, if not acquired in digital form. In case of the maps from 1857/60 and 1897/1901, the single map sheets were aligned manually to form one file. In case of the map from 1924/26, the single map sheets were processed separately. Using ArcGIS, the maps were then georectified according to the most recent topographic maps: Peta Rupabumi, 1:25,000, produced by BAKOSURTANAL in 1997-98, based on surveys in 1993-94 (8 map sheets). Georectification, by aligning map features to their real world position, brings the historical maps into coincidence or at least a best geometric fit with recent maps and satellite images within one common coordinate grid system. At the same time it provides the RMSE as a quantitative measure of the original map's accuracy. In line with the recent topographic maps, UTM Zone 49S (WGS 1984) was used as a common coordinate grid system. Georectification requires a minimum of four control points. Depending on the map and its topographic accuracy, between 11 and 31 control points were selected on each of the historical maps and aligned with their actual geographical position by linking them with their equivalent on the recent topographic maps (see Table 1). The considerable magnitude of environmental change, i.e. of sedimentation, river regulations, and settlement development (see Figures 2-8), limited the number and constrained equal distribution of control points, particularly in the northern part of the lagoon and the adjacent land areas. This rendered an assessment of spatial variations in map accuracy, as was done by Levin (2006), unfeasible. Most ground control points were identified based on topographic features, such as river intersections, bays, and capes (see Figure 5). Based on the control points, $1^{\text {st }}, 2^{\text {nd }}$, and $3^{\text {rd }}$ order polynomial transformations were performed. The resulting RMSE represent the residual error after transformation: the differences between the position of the control points after georectification and their actual geographic location. In addition to small methodological inaccuracies related to scanning resolution, the selection of control points, and possible-but negligible-geodetic inaccuracies, the RMSE in case of the maps analyzed can be assumed to mainly reflect the historical maps' planimetric accuracy.

Table 1 provides an overview of the historical maps analyzed and presents the results of the quantitative accuracy assessment. Not surprisingly, the later the maps were created, the higher their planimetric accuracy.

The earliest maps that were drawn as part of the charting expeditions between 1698 and 1739 are barely accurate enough to be georectified. Their limited topographic accuracy, resulting in a lack of suitable control points, and the collinearity of the few control points that could be identified constrained georectification and the determination of any mean planimetric errors by the means described above. The median error of $1510.5 \mathrm{~m}$ ( $1^{\text {st }}$ order polynomial transformation) for Coops' map can therefore not be compared with the results for any other maps. Due to their limited topographic and planimetric accuracy, these early sea charts could not be used for a quantitative analysis of shoreline changes. However, qualitative interpretation of these maps may provide information supporting the exploration of possible longer-term shoreline developments at times prior to the production of the earliest more accurate and quantitatively analyzable maps (see Lukas [forthcoming]).

The considerable difference between the median errors received for J. T. Busscher's map and the Kaart der Preanger Regentschappen, both of which were produced within the first two decades of the nineteenth century, demonstrates the usefulness of a quantitative planimetric accuracy assessment. Visual comparison of the two maps (Figures 3 and 4) and their comparison with the Residency map from 1857 (Figure 5) suggest that Busscher mapped the eastern shoreline of the lagoon's open water surface area with a higher level of topographic accuracy than the producers of the Kaart der Preanger Regentschappen, which simply depicts the eastern shoreline as a straight line, indicating 


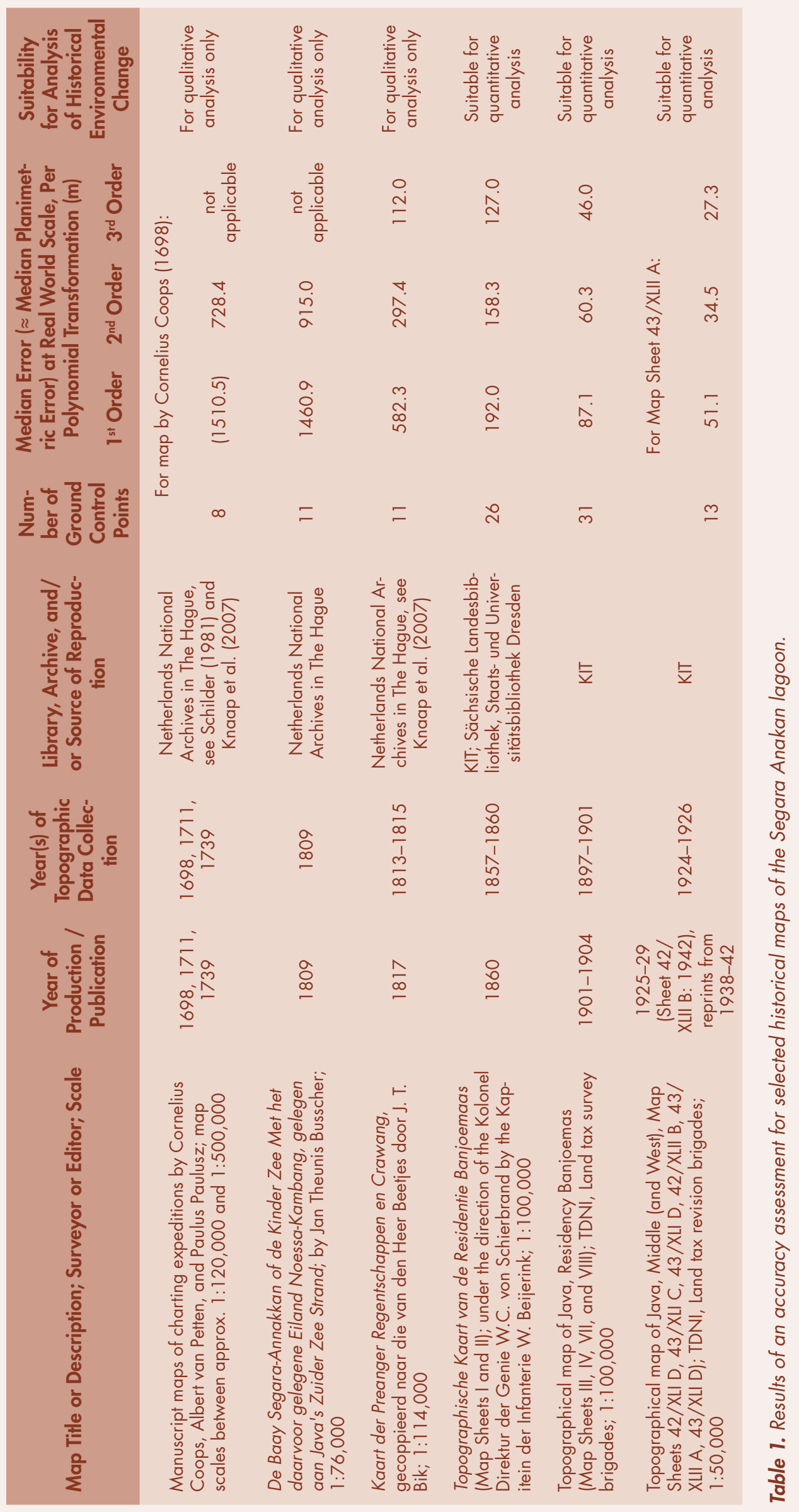


a lack of topographic knowledge. However, the result of the quantitative analysis shows that Busscher's map is clearly generally less accurate than the Kaart der Preanger Regentschappen (see Table 1), and this is important to consider when using the maps' contents for analysis.

The median errors obtained (see Table 1) are very large as compared to modern maps or satellite images, but they are comparable to the results obtained by other scholars for historical maps. Taking into account the different map scales and years of production, the median errors obtained for the maps produced between 1813/15 and 1924/26 are in a similar order of magnitude as those of the historical maps of Palestine analyzed by Levin et al. (Levin, Kark, and Galilee 2010; Levin 2006), the historical maps of North Carolina analyzed by Lloyd and Gilmartin (1987), and the historical maps of England that Bromberg and Bertness (2005) used to analyze salt marsh losses. In comparison extremely accurate are the Saxon Mile Sheets from 1780-84 for which Walz (2008) achieved a mean spatial accuracy of only $24 \mathrm{~m}$, and the nautical chart of the
Adra River delta in southeast Spain from 1855 for which Jabaloy-Sanchez et al. (2010) found an RMSE of $11.5 \mathrm{~m}$.

Preparing a systematic overview of the historical maps of an area including related carto-bibliographic information (see Lukas [forthcoming]) and results of an accuracy assessment (Table 1) provides a solid basis for a cartographic analysis of historical environmental change. However, based on this information and the quantitative accuracy measures alone, the question posed at the beginninghow accurate the cartographic material needs to be at minimum in order to be used for which kind of analysis - cannot be conclusively answered yet. As was noted by Levin (2006) and as will be demonstrated below, the analytical suitability of historical maps also depends on the magnitude of the environmental changes to be investigated; in other words the maps' reliability depends on both their accuracy and their utilization. Therefore the next section presents the methods and results of the shoreline change analysis carried out, before the following section returns to the question of map accuracy.

\section{RECONSTRUCTING THE LAGOON'S HISTORICAL WATER SURFACE AREA}

AnAlysis of SHORELINE VARIABILITy and related methodological challenges has been a growing research field in the past two decades (see, for example, Boak and Turner [2005], Crowell, Leatherman, and Buckley [1991], Moore [2000], and Monmonier [2008]). Knowledge of past shoreline changes can be relevant for various contemporary management issues, including ecological, legal, regulatory, and engineering questions. In case of ocean shorelines, the accurate detection of the land-water boundary is constrained by its great fluctuating variability over various time scales, caused by waves, currents, tides, and temporally variable accumulation and erosion processes. Therefore, identification and mapping of contemporary shorelines, let alone their historical reconstruction, remains a methodological challenge.

In the case of the Segara Anakan lagoon, fluctuating variability is largely confined to the influence of tides and is thus less problematic than in case of open ocean shorelines. Yet the fuzzy, barely visible character of the land-water boundary within the mangrove forest areas potentially introduces uncertainty. However, since aggradation has consistently been accompanied by the expansion of mangroves or other vegetation, the most practical and fairly accurate approach is to define the water surface area of the lagoon as the area that is covered by water at high tide but that is not vegetated. This area is demarcated from the sea by the two tidal channels and comprises the lower reaches of the tributary rivers. It also includes the entire channel network in the eastern part of the lagoon and the areas of the pile villages, which existed within the open water surface area until the first half of the twentieth century and which are depicted in the respective maps (see Figures 4-7).

Based on the quantitative accuracy assessment of the historical maps presented in Table 1 and a qualitative area-specific comparison of these maps, the historical maps from 1857-60, 1897-1901, and 1924/26 were selected as a solid basis for the shoreline change analysis. The quantitative accuracy assessment also suggests including the map from 1813/15. However, qualitative comparison and overlay of this map with the more recent maps indicates its limited accuracy particularly in the areas affected by shoreline changes - areas where the limited topographic accuracy of the map and the environmental changes themselves did not allow for the identification of suitable control points. The unrealistically straight line that represents the eastern shoreline in this map (see Figure 4, compared 
with the maps from 1809 and 1857-60, shown in Figures 3 and 5) indicates the mapmakers' limited knowledge of this part of the lagoon and hence low levels of topographic accuracy in this section of the map.

In addition to the historical maps, one section of a Corona Satellite Image, taken in 1962 and scanned with a resolution of $1,800 \mathrm{dpi}$, was georectified on the basis of the recent topographic maps, using a $2^{\text {nd }}$ order polynomial transformation, with an RMSE of $14.1 \mathrm{~m}$. In addition, a number of satellite images taken between 1973 and 2013 (see Table 2) were georectified with negligibly small RMSEs, if not acquired in pre-processed form.

On the basis of the three historical maps ( $3^{\text {rd }}$ order polynomial transformation) and the satellite images, the historical course of the Segara Anakan lagoon's shorelines was

\begin{tabular}{|ccc|}
\hline Type of Data & $\begin{array}{c}\text { Date of } \\
\text { Acquisition }\end{array}$ & $\begin{array}{c}\text { Spatial } \\
\text { Resolution }\end{array}$ \\
\hline Corona, FTV-1126, Mission No. 9034 & 17.05 .1962 & $140 \mathrm{~m}$ \\
Landsat MSS & 01.08 .1973 & $79 \mathrm{~m}$ \\
Landsat MSS & 21.06 .1983 & $79 \mathrm{~m}$ \\
Landsat TM & 23.05 .1993 & $30 \mathrm{~m}$ \\
Landsat ETM+ & 03.03 .2013 & $30 \mathrm{~m}$
\end{tabular}

Table 2. Satellite images used for shoreline reconstruction in combination with the historical maps (The Landsat TM image was acquired from BTIC Dataport, Indonesia; all other images were acquired from USGS).

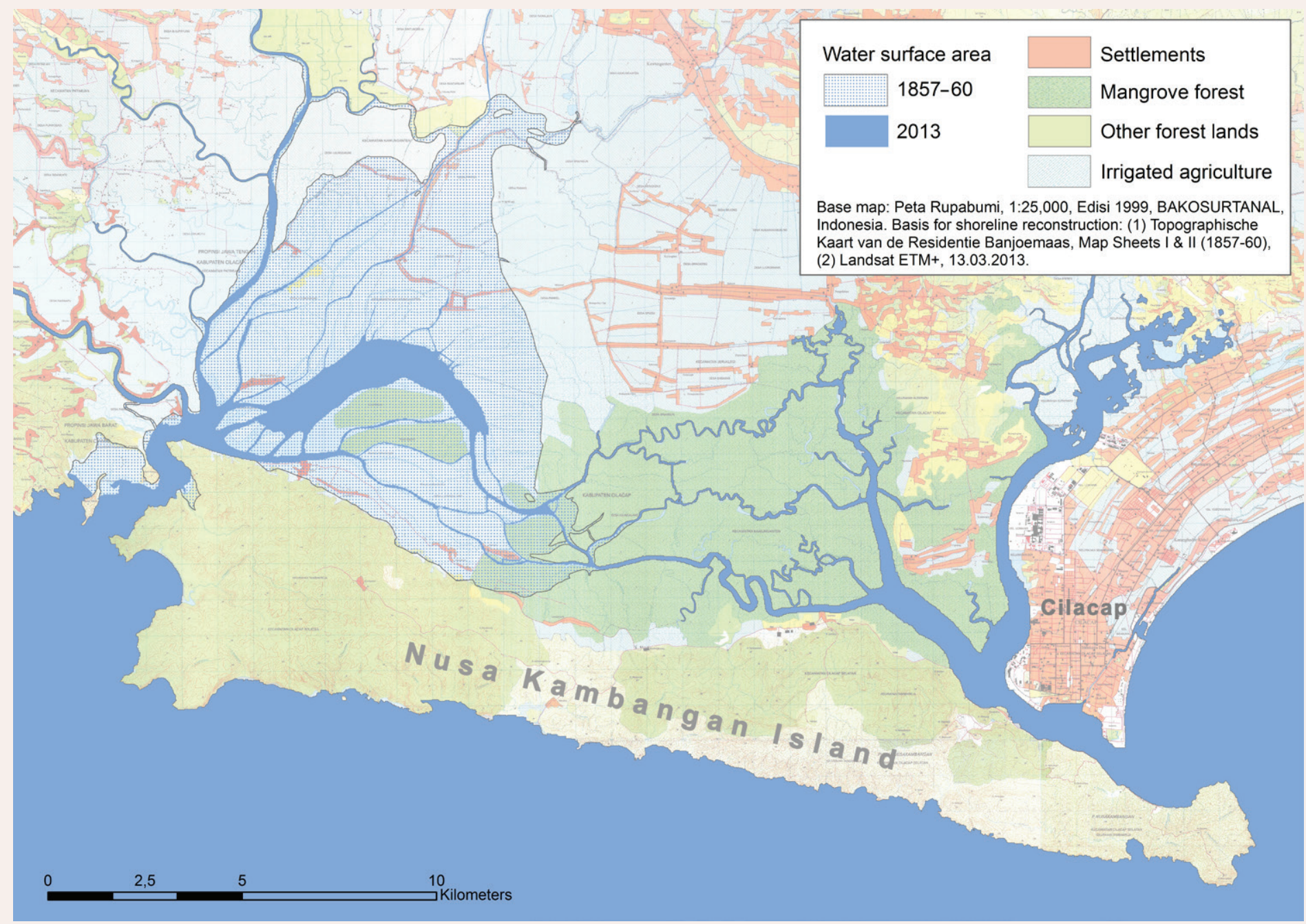

Figure 9. Change in the water surface area of the Segara Anakan lagoon between 1857/60 and 2013. Most of the silted-up area is presently covered by (partly degraded) mangroves and shrubs, (partly abandoned) aquaculture ponds, agricultural fields, and settlements (c.f. Ardli and Wolff [2009]). 


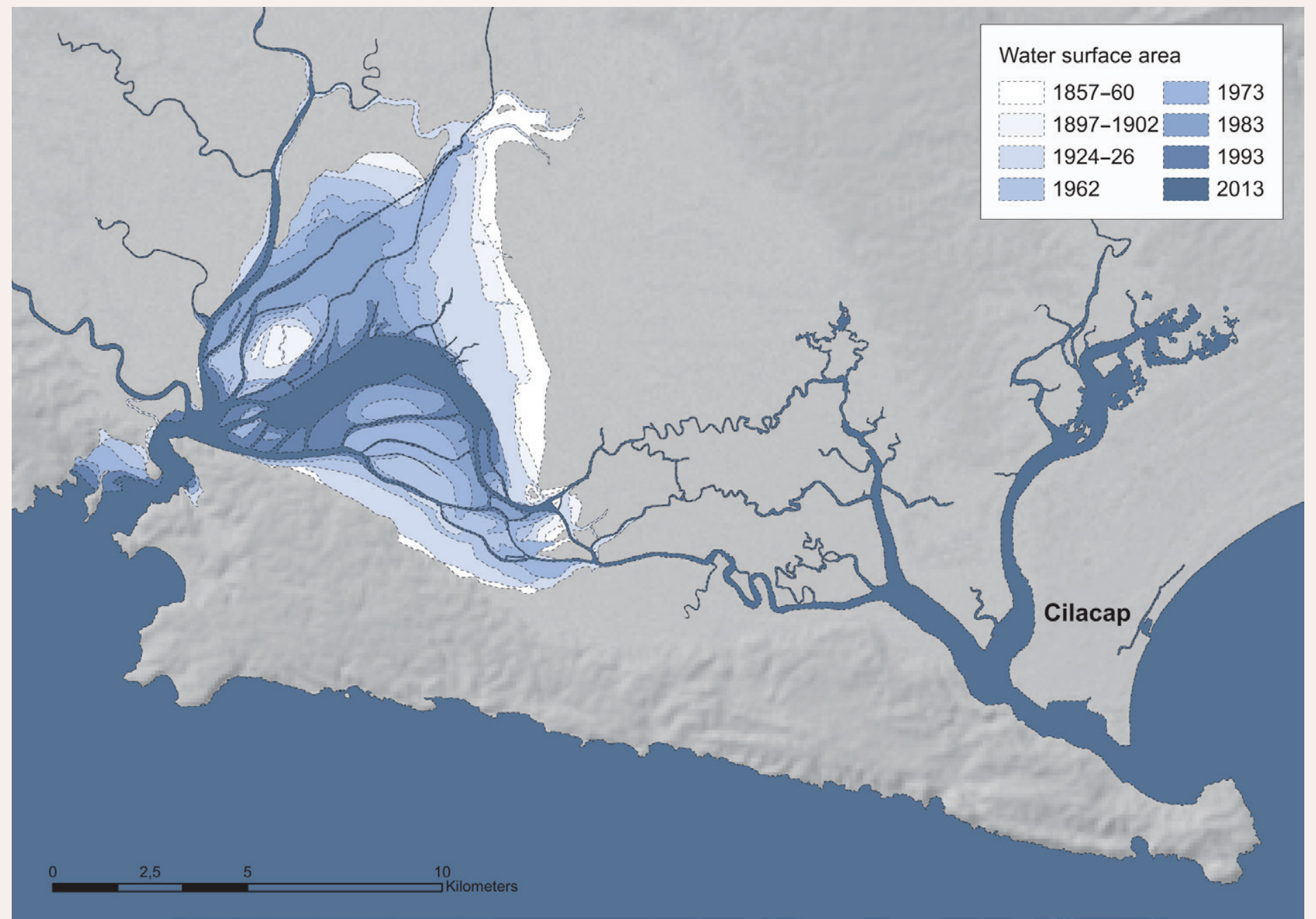

Figure 10. The reconstructed historical lagoon shorelines illustrate the siltation process between 1857/60 and 2013. Base map: SRTM (Shuttle Radar Topography Mission), available from the USGS. Reconstructed shorelines based on maps and satellite images listed in Tables 1 and 2.

manually delineated. Figures 9 and 10 present the results. They depict the dramatic decline in the lagoon's water surface area, providing a two-dimensional picture of lagoon sedimentation between $1857 / 60$ and 2013. Shoreline aggradation accelerated between $1857 / 60$ and the late 1980 s or early 1990 s and slowed down thereafter. The latter is partly related to lagoon dredging in the early 2000 s (ADB 2006), but might also reflect the possibility of approaching a state where the proportion of riverine sediment input that is not deposited in the lagoon but carried out into the ocean increases in line with the shrinking of the water body.

Critically questioning these results, one could argue that it is uncertain whether the makers of the historical maps followed a similar approach in defining the lagoon's shorelines as has been used in analyzing their maps. Some of the historical maps indicate that water depths were already fairly low in parts of the lagoon. For example, Busscher's map from 1809 (Figure 4) delineates deeper channels from the surrounding shallower water areas, using different signatures. It could be argued that the differences in the course of shorelines and in the number and size of islands situated within the lagoon on the various historical maps do not indicate physical changes, but result from different approaches of different mapmakers in delineating shorelines. However, a number of considerations clearly support the conclusion that the major differences between the maps do reflect real physical changes (i.e., aggradation): (1) certain islands, such as those at the south-eastern edge of the open water surface area, were consistently drawn by all map makers with increasing sizes over time; (2) other islands, such as those in the western part of the lagoon, were not depicted on earlier maps but were later 
drawn by all mapmakers with increasing sizes over time; (3) the northern and eastern shorelines of the lagoon were over time depicted further and further to the south and west respectively, while the location of other (also vegetated) shoreline sections that were not affected by sedimentation (e.g., within the eastern channel network) did not vary between map makers and over time; and (4) the early spatiotemporal trends observed on the time sequence of historical maps continued during the period covered by remotely sensed data.

However, a major limitation of this historical cartographic analysis of aggradation is its confinement to the water surface area, while changes in water depth remain unknown. An analysis of the latter would require a time series of historical depth soundings with a high spatial resolution, which does not exist. In addition, changes of the lagoon's water surface area and even of its volume cannot be directly translated into temporal changes of riverine sediment input, since the proportion of sediments that is deposited in the lagoon and not transported out to the ocean must have changed over time. Nevertheless, given the large magnitude of change in aggradation rates, it seems plausible to assume that the historical cartographic reconstruction of the water surface area presented here provides at least a rough picture of the temporal dynamics of riverine sediment input, albeit not with proportionality. In a next step, a time sequence of the various potential drivers of sedimentation or information from sediment core analyses could be combined with the maps of change presented here.

\section{LINKING MAP ACCURACY WITH ENVIRONMENTAL CHANGE RATES}

FinALLy, THE RESUlts of the shoreline change analysis presented in Figures 9 and 10 should be linked with the quantitative map accuracy measures. This is part of the necessary critical reflection on the methodological approach used and, at the same time, brings us back to the question posed at the beginning: how accurate does historical cartographic material need to be at minimum in order to be used for which kind of analysis? The "required" or "minimum" accuracy level of historical maps for analyzing environmental changes depends considerably on the kind and magnitude of the changes to be analyzed. Table 3 links the median planimetric errors of the historical maps used with the rates of shoreline change detected. It shows that the rates of shoreline change were so extraordinarily high that they clearly exceed the magnitude of potential uncertainty introduced by map inaccuracies and the analytical process.

Ratios between the rates of the environmental changes to be analyzed and planimetric map accuracy may serve as a general quantitative indicator for the analytical suitability of historical maps. The ratio $r$ is determined as follows:

$$
r=\frac{s}{\Delta x_{1,2}}
$$

where $s$ is the total shoreline change rate during the respective period and $\Delta x_{1,2}$ the median planimetric errors of the respective maps (Map 1,2) at real world scale.
In the research presented here, the ratios $r$ calculated for the different shoreline sections and maps indicate that the shoreline change rates detected were in almost all cases between 6.5 and 106.4 times higher than the median planimetric errors of the respective maps (see Table 3). Such high ratios between environmental change rates and map inaccuracy clearly indicate the historical maps' suitability for detecting environmental changes with potential errors that are acceptably small for most purposes. In the case of the map from 1857/60 (when overlayed with the map from 1897/1901), the ratios between environmental change rate and median planimetric error of 2.4-6.4, depending on the shoreline section, indicate higher levels of uncertainty, but also show that the changes detected still clearly exceed the levels of potential inaccuracy. When analyzing a time-sequential series of maps to detect spatial changes continuously directed in one single direction (as in the research presented here), comparably low ratios between environmental change rates and map inaccuracy may usually still be acceptable, while analysis of fluctuating environmental changes may require higher levels of planimetric map accuracy.

While the ratios proposed above provide a practical and easy to calculate indicator for the suitability of historical maps for particular analytical purposes, the reliability of the actual results from cartographic analyses may be quantified using combined uncertainty measures. As environmental change rates are usually based on information from 


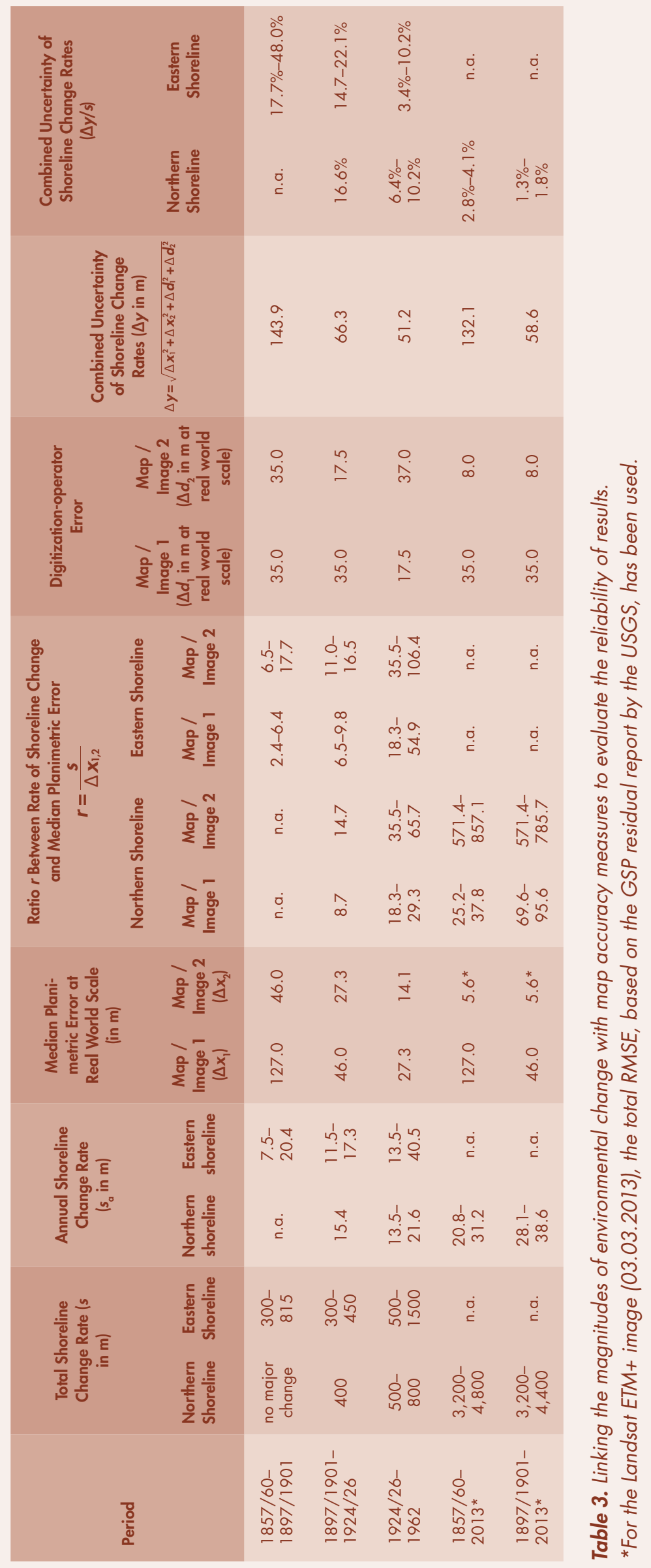


two different maps or images, their uncertainty $\Delta y$ can be derived from the respective maps' planimetric errors $\Delta x_{1}$ and $\Delta x_{2}$, applying the law of propagation of uncertainty:

$$
\Delta y=\sqrt{\Delta x_{1}^{2}+\Delta x_{2}^{2}}
$$

In addition, a digitization-operator error has been incorporated in determining the uncertainty of shoreline change rates (based on Crowell, Leatherman, and Buckley 1991; M.-Muslim, Foody, and Atkinson 2007). In case of the historical maps, digitization and operator errors are estimated at $0.25 \mathrm{~mm}$ each at map scale (following Crowell, Leatherman, and Buckley [1991]), resulting in a combined digitization-operator error $\Delta d_{1,2}$ of $0.35 \mathrm{~mm}$ at map scale:

$$
\Delta d_{1,2}=\sqrt{0.25 \mathrm{~mm}^{2}+0.25 \mathrm{~mm}^{2}}
$$

Table 3 lists the ground distance equivalent of the digitization-operator error based on the individual map scales. In case of the aerial photographs and satellite images, estimates of the positional accuracy of the shorelines detected are based on M.-Muslim, Foody, and Atkinson (2007), who determined shoreline prediction accuracies depending on the spatial resolution of the satellite images of $3.16-4.25 \mathrm{~m}$ in case of a resolution of $16 \mathrm{~m}$ and $5.73-8.67 \mathrm{~m}$ in case of a resolution of $32 \mathrm{~m}$. Based on these results and assuming a near-proportional relationship between resolution and positional accuracies determined, positional accuracies of $8 \mathrm{~m}$ in case of the Landsat ETM+ image from 2013 (30m spatial resolution) and of $37 \mathrm{~m}$ in case of the Corona image from 1962 (140m spatial resolution) were used.

Thus, based on the respective maps' planimetric errors $\Delta x_{1}$ and $\Delta x_{2}$ and the respective digitization-operator errors $\Delta d_{1}$ and $\Delta d_{2}$, the combined uncertainty is determined as follows:

$$
\Delta y=\sqrt{\Delta x_{1}^{2}+\Delta x_{2}^{2}+\Delta d_{1}^{2}+\Delta d_{2}^{2}}
$$

The combined uncertainty measures can be expressed in absolute $(\Delta y)$ or relative $(\Delta y / s$ as a percentage of the shoreline change rate) terms. As shown in Table 3, the shoreline change rates detected for the period 1857/60-1897/1901 are marked by uncertainties of $17.7-48.0 \%$, depending on the shoreline section, while the shoreline change rates detected for the period 1924/26-1962 are marked by uncertainty levels of only $3.4-10.2 \%$.
The lower two rows of Table 3 clearly illustrate the dependence of the "required" or "minimum" levels of map accuracy on the rates of the environmental changes to be analyzed. When analyzing shoreline change rates for the entire period from 1857/60 to 2013, even the use of the comparably inaccurate map from 1857/60 yields results that are marked by uncertainty levels of only $2.8-4.1 \%$, because the shoreline change rates for this period exceed the map inaccuracy measure by a factor of 25-38.

The number of studies that have directly linked environmental change rates with quantitative map accuracy measures is relatively limited to date. While some cartographers' work is completely devoted to the analysis of map accuracy (e.g., Jenny and Hurni [2011], Jenny [2006], Bönisch [1967], Nell [2009]), other scholars who used historical maps for analyzing environmental changes did partly not link their results with map accuracy measures, though they provided georectification errors (e.g. Khromova et al. [2006], Jabaloy-Sanchez et al. [2010], Bromberg, and Bertness [2005]). A comparison of the georectification errors provided by the authors with the environmental change rates detected shows, in case of the study of salt marsh losses by Bromberg and Bertness (2005), that environmental change rates clearly exceeded potential errors introduced by planimetric map accuracy. In fact, since many of the analyzed salt marshes were completely lost, planimetric map accuracy seems less relevant than topographic accuracy. In case of the study of Jabaloy-Sanchez et al. (2010), who reconstructed coastline changes in the Adra River Delta, the georectification result (RMSE of $11.5 \mathrm{~m}$ for a map from 1855 and $237.3 \mathrm{~m}$ for a map from 1873/76) combined with the shoreline change rate they detected for this period $(16 \mathrm{~m}$ per year, thus about $288 \mathrm{~m}$ in total from 1855 to 1873 ) yields ratios between environmental change rate and RMSE of 25.0 for the map from 1855, but of only 1.2 for the map from 1873. The latter indicates high uncertainty of results. Also Tanaka et al. (2007), who analyzed coastline changes in the Miyagi and Fukushima Prefectures in Japan, did not link their quantitative map accuracy measures with the coastline changes identified. Their georectification results (RMSE $<40 \mathrm{~m}$ ) and their shoreline change rates of about 220-550m between 1801 and 1904, as depicted in a map, yield ratios between environmental change rate and map accuracy measures of at least 5.6-14.1.

The work of Levin (2006) is one of the few studies that directly links map accuracy and environmental change 
rates. His dune movement rates of 3.98-6.32m/year and his maximum data resolution error (which in addition to the RMSE comprises a survey, digitization, and feature-boundary error) of $2.96 \mathrm{~m} /$ year yield a ratio of $1.3-$ 2.1 , indicating relatively high levels of uncertainty. Also Salerno et al. (2008) compared environmental change rates with map accuracy. They analyzed surface area variations of glaciers in Nepal, comparing maps from the 1950s and the early 1990s. Linking their areal errors of 0.1 to $3.6 \mathrm{~km}^{2}$ for individual glaciers with the surface differences of 0.1 to $6.1 \mathrm{~km}^{2}$ detected for the respective glaciers, the ratios between environmental change rates and analytical accuracy varied between 0.6 and 10.0. That is, in one case $(r=0.6)$ the uncertainty measure exceeded the glacier change rate detected.

The quantitative measures proposed above support the appraisal of the historical maps' suitability for analyzing environmental changes. Yet, in some cases, and this particularly applies to maps with higher levels of inaccuracy, quantitative measures alone might not be sufficient to assess the maps' suitability for analysis. The example of the Kaart der Preanger Regentschappen en Crawang from 1813/15 illustrates this. While the RMSEs obtained for this map are somewhat comparable to those obtained for the map from 1857/60, qualitative comparison and overlay of this map with more recent maps show its comparatively low level of reliability, particularly in areas where the limited topographic accuracy combined with shoreline changes did not allow for the identification of ground control points. Also the contradicting comparison of topographic and planimetric accuracy between the map from 1813/15 and the map by J. T. Busscher from 1809 noted above supports the argument that quantitative accuracy measures should be combined with a qualitative, sometimes area-specific, appraisal of the other dimensions of accuracy.

\section{CONCLUSION}

The case of THE shrinking Segara Anakan lagoon presented in this paper illustrates the large, to date clearly underutilized, potential of the historical cartographic material of Southeast Asia for analyzing spatial-temporal patterns of historical environmental changes. In the case presented, a combined analysis of historical maps and recent satellite images is the most obvious, most feasible, and - in terms of spatial coverage and resolution-also the most complete approach to analyze historical shoreline dynamics. However, the limited availability and accuracy of early historical cartographic material limits the temporal scale of analysis, poses methodological challenges, and introduces uncertainty.

The shoreline change analysis presented demonstrates that the question of how accurate historical cartographic material needs to be at minimum in order to be used for quantitatively reconstructing historical environmental changes considerably depends on the kind and magnitude of the dynamics to be analyzed. On the one hand, large magnitudes of environmental change potentially constrain the accuracy analysis and rectification of historical maps due to the resulting lack of suitable control points. On the other hand, the larger the magnitude of the environmental changes to be analyzed, the higher the levels of planimetric map inaccuracy that are acceptable.
Hence, determining ratios between environmental change rates and median planimetric map accuracy is crucial to assess a map's suitability for quantitative analysis. This should be combined with a qualitative appraisal of the maps, taking into account carto-bibliographic information and the various dimensions of map accuracy. In the case presented here, ratios between environmental change rates and median planimetric errors of mostly between 6.5 and $>100$ clearly indicate the maps' suitability for quantitative analysis. In case of analyzing continuous, single-directed environmental changes using a time-sequential series of maps, lower ratios between environmental change rates and planimetric map accuracy may be acceptable than in case of fluctuating changes.

Combined uncertainty measures, derived from the planimetric accuracies of the maps or images used and the environmental change rates detected, indicate the reliability of the results from cartographic analyses. In the case presented here, the uncertainty of the shoreline change rates detected for the historical time spans vary between 3 and $48 \%$, depending on the period (i.e. the maps used) and the shoreline section. In the case of large magnitudes of environmental change, the use of even fairly inaccurate historical maps with planimetric accuracy levels of, for example $127 \mathrm{~m}$, in combination with recent satellite images, can 
provide surprisingly precise environmental change rates, with uncertainty levels of only 1-4\%.

Last but not least, the results of the shoreline change analysis - the maps of change presented here-may be regarded as one milestone towards a better understanding of environmental changes in the Segara Anakan lagoon region and support further inquiry into the long-term dynamics and drivers of lagoon transformation.

\section{ACKNOWLEDGEMENTS}

I would like to thank Michael Flitner and Kathleen Schwerdtner Máñez Costa for the discussions which contributed to the initiation of this research; Ferjan Ormeling for his comments regarding the history of mapping in the Segara Anakan region; Manfred Buchroithner for his information and contacts; and Jill Heyde as well as three anonymous reviewers for their feedback on the manuscript. Thanks also go to Elger Heere, John W. Hessler, Vladimiro Valerio, Chris Fleet, Daniel N. Pagano, and all who contributed valuable comments to my questions about map accuracy via the email list MapHist. The research was carried out by the author when he was affiliated with the Leibniz Center for Tropical Marine Ecology Bremen $\mathrm{GmbH}$ (ZMT). It was part of the research programme SPICE II (Science for the Protection of Indonesian Coastal Marine Ecosystems) and funded by the German Federal Ministry of Education and Research (Grant No. 08F0391A). The author was also supported by the Bremen International Graduate School for Marine Sciences (GLOMAR), which is funded by the German Research Foundation (DFG) within the frame of the Excellence Initiative by the German federal and state governments to promote science and research at German universities.

\section{REFERENCES}

ADB. 2006. Indonesia: Segara Anakan Conservation and Development Project. Completion Report. Asian Development Bank.

Ardli, E. R. and M. Wolff. 2008. "Quantifying Habitat and Resource Use Changes in the Segara Anakan Lagoon over the Past 25 Years." Asian Journal Of Water, Environment And Pollution 4: 59-67.

_. 2009. "Land Use and Land Cover Change Affecting Habitat Distribution in the Segara Anakan Lagoon, Java, Indonesia.” Regional Environmental Change 9 (4): 235-243. doi: 10.1007/ s10113-008-0072-6.

\section{ASEAN/US CRMP. 1992. The Integrated Management} Plan for Segara Anakan-Cilacap, Central Java, Indonesia. ICLARM Technical Publication Series 12.: Association of Southeast Asian Nations United / United States Coastal Resources Management Project, Directorate General of Fisheries, Indonesia.
Batterbury, S. P. J. and A. J. Bebbington. 1999. "Environmental Histories, Access to Resources and Landscape Change: An Introduction." Land Degradation E Development 10 (4): 279-289. doi: 10.1002/(Sici)1099-145x(199907/08)10:4<279::AidLdr364>3.0.Co;2-7.

Beumée, J. G. B. 1929. Bandoeng - Tjilatjap - Djokja (Botanical Trip). Buitenzorg: Herbarium and Museum for Systematic Botany

Bird, C. F., A. Soegiarto, and K. Soegiarto. 1980. "Proceedings of the Workshop on Coastal Resources Management in the Cilacap Region." Gadjah Mada University, Yogyakarta, Indonesia, 20-24 August 1980.

Blakemore, M. J. and J. B. Harley. 1980. “Concepts in the History of Cartography. A Review and Perspective." Cartographica 17: 1-120. doi: 10.3138/ G602-RM23-8207-0V5U. 
Boak, E. H. and I. L. Turner. 2005. "Shoreline Definition and Detection: A Review." Journal of Coastal Research 21 (4): 688-703. doi: 10.2112/03-0071.1.

Bönisch, F. 1967. "The Geometrical Accuracy of 16th and 17th Century Topographical Surveys." Imago Mundi 21: 62-68.

Bromberg, K. D. and M. D. Bertness. 2005.

"Reconstructing New England Salt Marsh Losses Using Historical Maps.” Estuaries 28 (6): 823-832. doi: 10.1007/Bf02696012.

Brookfield, H. 1999. "Environmental Damage:

Distinguishing Human from Geophysical Causes." Global Environmental Change Part B: Environmental Hazards 1 (1): 3-11. doi: 10.1016/ S1464-2867(99)00004-2.

Chapman, G. and T.S. Driver. 1996. Time-Scales and Environmental Change. London, New York: Routledge.

Crowell, M., S. P. Leatherman and M. K. Buckley. 1991. "Historical Shoreline Change: Error Analysis and Mapping Accuracy." Journal of Coastal Research 7 (3): 839-852. doi: 10.2307/4297899.

Dudley, R.G. 2000. Segara Anakan Fisheries Management Plan. Segara Anakan Conservation and Development Project, Components $B \in \mathcal{E} C$, Consultant's Report.

ECI. 1994. Segara Anakan Conservation and Development Project. Engineering Consultants, Inc., Asian Development Bank (ADB).

Haase, D., U. Walz, M. Neubert, and M. Rosenberg. 2007. "Changes to Central European LandscapesAnalysing Historical Maps to Approach Current Environmental Issues, Examples from Saxony, Central Germany." Land Use Policy 24 (1): 248-263. doi: 10.1016/j.landusepol.2005.09.003.

Hadisumarno, S. 1964. “Segara Anakan.” Indonesian Journal of Geography 4 (8): 30-37.

1979. "Coastline Accredition in Segara Anakan, Central Java, Indonesia." Indonesian Journal of Geography 9 (37): 45-52.
Jabaloy-Sanchez, A., F. J. Lobo, A. Azor, P. Barcenas, L. M. Fernandez-Salas, V. D. del Rio, and J. V. PerezPena. 2010. "Human-Driven Coastline Changes in the Adra River Deltaic System, Southeast Spain." Geomorphology 119 (1-2): 9-22. doi: 10.1016/j. geomorph.2010.02.004.

Jenny, B. 2006. "Analysis of the Planimetric Accuracy of Historical Maps with Digital Tools.” In Proceedings of the First international Workshop "Digital Approaches to Cartographic Heritage," Thessaloniki, Greece, 18-19 May 2006, National Center for Maps and Cartographic Heritage.Jenny, B. and L. Hurni. 2011. "Studying Cartographic Heritage: Analysis and Visualization of Geometric Distortions." Computers E Graphics 35 (2): 402-411. doi: 10.1016/j.cag.2011.01.005.

Khromova, T. E., G. B. Osipova, D. G. Tsvetkov, M.B. Dyurgerov, and R. G. Barry. 2006. "Changes in Glacier Extent in the Eastern Pamir, Central Asia, Determined from Historical Data and Aster Imagery." Remote Sensing of Environment 102 (1-2): 24-32. doi: 10.1016/j.rse.2006.01.019.

Knaap, G., J. R. van Diessen, W. Leijnse, and M. P. B. Ziellemans. 2007. Grote Atlas Van De Verenigde OostIndische Compagnie / Comprehensive Atlas of the Dutch United East India Company. Volume II: Java En Madoera I Java and Madura. Voorburg, The Netherlands: Uitgeverij Maior / Atlas Maior.

Laxton, P. 1976. "The Geodetic and Topographical Evaluation of English County Maps, 1740-1840.” The Cartographic Journal 13 (1): 37-54. doi: 10.1179/ caj.1976.13.1.37.

Levin, N. 2006. "The Palestine Exploration Fund Map (1871-1877) of the Holy Land as a Tool for Analysing Landscape Changes: The Coastal Dunes of Israel as a Case Study." The Cartographic Journal 43 (1): 45-67. doi: 10.1179/000870406x93508.

Levin, N., R. Kark and E. Galilee. 2010. "Maps and the Settlement of Southern Palestine, 1799-1948: An Historical/GIS Analysis.” Journal of Historical Geography 36 (1): 1-18. doi: 10.1016/j.jhg.2009.04.001. 
Lloyd, R. and P. Gilmartin. 1987. "The South Carolina Coastline on Historical Maps: A Cartometric Analysis." The Cartographic Journal 24 (1): 19-26. doi: 10.1179/caj.1987.24.1.19.

Locke, W. W. and W. K. Wyckoff. 1993. "A Method for Assessing the Planimetric Accuracy of Historical Maps: The Case of the Colorado-Green River System." The Professional Geographer 45 (4): 416-424. doi: 10.1111/j.0033-0124.1993.00416.x.

Lukas, M. C. 2013."Political Transformation and Watershed Governance in Java: Actors and Interests." In Governing the Provision of Ecosystem Services, edited by R. Muradian and L. M. Rival, 111-32. Dordrecht / New York: Springer.

. 2014. "Eroding Battlefields: Land Degradation in Java Reconsidered." Geoforum 56: 87-100. doi: 10.1016/j.geoforum.2014.06.010.

- Forthcoming. "Neglected Treasures: Linking Historical Cartography with Environmental Changes in Java, Indonesia." Cartographica.

M.-Muslim, A., G. M. Foody and P. M. Atkinson. 2007. "Shoreline Mapping from Coarse-Spatial Resolution Remote Sensing Imagery of Seberang Takir, Malaysia.” Journal of Coastal Research 23 (6): 1399-1408. doi: 10.2112/04-0421.1.

Messerli, B., M. Grosjean, T. Hofer, L. Nunez, and C. Pfister. 2000. "From Nature-Dominated to HumanDominated Environmental Changes." Quaternary Science Revierws 19 (1-5): 459-479. doi: 10.1016/ S0277-3791(99)00075-X.

Monmonier, M. 2008. Coast Lines: How Mapmakers Frame the World and Chart Environmental Change. Chicago: University of Chicago Press. doi: 10.7208/ chicago/9780226534046.001.0001.

Moore, L.J. 2000. "Shoreline Mapping Techniques.” Journal of Coastal Research 16 (1): 111-124. http://www. jstor.org/stable/4300016.

Nell, D. 2009."Methoden der Genauigkeitsanalyse Historischer Karten am Beispiel der Gradkartenblätter 1:25.000 Innsbruck und Lienz der Dritten Österreichischen Landesaufnahme." Universität Wien.
Olive, C.A. 1997."Land Use Change and Sustainable Development in Segara Anakan, Java, Indonesia: Interactions among Society, Environment and Development." PhD diss., University of Waterloo.

Pearson, A. and P. Collier. 1998. "The Integration and Analysis of Historical and Environmental Data Using a Geographical Information System: Landownership and Agricultural Productivity in Pembrokeshire C.1850." Agricultural History Review 46: 162-176. http://www.jstor.org/stable/40275253.

Pearson, B. C. 2005. "Comparative Accuracy in Four Civil War Maps of the Shenandoah Valley: A GIS Analysis." Professional Geographer 57 (3): 376-94. doi: 10.1111/j.0033-0124.2005.00485.x.

\section{PRC-ECI. 1987. Segara Anakan Engineering Measures} Study. Main Report. Denver, USA and Banjar, Indonesia: PRC Engineering Consultants, Inc. and Ministry of Public Works Indonesia.

Purba, M. 1991. "Impact of High Sedimentation Rates on the Coastal Resources of Segara Anakan, Indonesia." In ICLARM Conference Proceedings 22, 143-52: National University of Singapore; National Science and Technology Board, Singapore and International Center for Living Aquatic Resources Management, Philippines.

Salerno, F., E. Buraschi, G. Bruccoleri, G. Tartari, and C. Smiraglia. 2008. "Glacier Surface-Area Changes in Sagarmatha National Park, Nepal, in the Second Half of the 20th Century, by Comparison of Historical Maps." Journal of Glaciology 54 (187): 738-752.

Schaafsma, J. M. G. 1926. Een en ander over de Segara Anakan (Kinderzee). Weltevreden: Jaarverslag van den Topographischen Dienst in NederlandschIndië.Schilder, G. 1978. "Paulus Paulusz en de Kartering Van Java's Zuidkust." Kartografisch Tijdschrift 9: 3-27.

\section{1. "The Charting of the South Coast of} Java." Archipel: Etudes Interdisciplinaires sur le Monde Insulindien 22: 87-104. doi: 10.3406/arch.1981.1672. 
Schilder, G., F. J. Ormeling, P. P. W. J. van den Brink, J. Moerman, and H. Ferwerda. 2006. Grote Atlas Van De Verenigde Oost-Indische Compagnie / Comprehensive Atlas of the Dutch United East India Company. Volume I: Atlas Isaak De Graaf/Atlas Amsterdam. Voorburg, The Netherlands: Uitgeverij Maior / Atlas Maior.

Słowik, M. 2013. “Transformation of a Lowland River from a Meandering and Multi-Channel Pattern into an Artificial Canal: Retracing a Path of River Channel Changes (the Middle Obra River, W Poland)."

Regional Environmental Change 13 (6): 1287-1299. doi: 10.1007/s10113-013-0453-3.

Soewondho, B.S. 1984. "Program Terpadu Segara Anakan dan Pulau Nusakambangan Sebagai Alternatip." Badan Perencanaan Pembangunan Daerah (BAPPEDA), Kabupaten Daerah Tingkat II, Cilacap, Propinsi Jawa Tengah, Indonesia.

Tanaka, H., G. Takahashi, H. Matsutomi, and N. Izumi. 2007. "Application of Old Maps for Studying Long-Term Shoreline Change." In Coastal Engineering 2006, edited by J. M. Smith, 4022-4034. San Diego, California.
Tejakusuma, I.G. 2006. "Analisis Faktor dan Implikasi Penyusutan Laguna Segara Anakan.” Alami, Journal Air, Lahan, Lingkungan dan Mitigasi Bencana 11 (3): 35-40.

Walz, U. 2008. "Monitoring of Landscape Change and Functions in Saxony (Eastern Germany)-Methods and Indicators." Ecological Indicators 8 (6): 807-817. doi: 10.1016/j.ecolind.2007.09.006.

White, A. T., P. Martosubroto and M. S. M. Sadorra. 1989. The Coastal Environmental Profile of Segara Ankan-Cilacap, South Java, Indonesia. ICLARM, Technical Reports.

Yuwono, E., T. C. Jennerjahn, I. Nordhaus, E. A. Riyanto, M. H. Sastranegara, and R. Pribadi. 2007. "Ecological Status of Segara Anakan, Indonesia: A Mangrove-Fringed Lagoon Affected by Human Activities." Asian Journal of Water, Environment and Pollution 4 (1): 61-70. 